\title{
SARTORIAL/RHETORICAL STYLE: COSTUME AND APPEARANCE IN VICTORIAN FALLEN WOMAN FICTION
}

\begin{abstract}
In this article, I investigate the visual rhetoric of costume and appearance as evidenced by fallen women in three novels: Ruth in Ruth, Lady Isabel in East Lynne, and Lady Audley in Lady Audley's Secret. I argue that each character's appearance is a kind of visual rhetoric. Clothing and jewelry are used to make an argument, and costumes and physical appearance are imbued with meaning; the fallen women in the novels use costumes and alter their physical appearance to perform different identities. Although none is ultimately successful at disguising herself, each character's attempt to use costuming highlights the importance of sartorial/rhetorical style in Victorian fallen women fiction.
\end{abstract}

Key words: Victorian, fiction, rhetoric, women

\section{Introduction}

In her landmark study that encompasses Victorian literature and visual art, "The Rise of the Fallen Woman", Nina Auerbach complicates our understanding of the cultural myth of the fallen woman, arguing that portrayals of fallen women "... mediate between abasement and exaltation, hiding images of women's triumph in representations of her punishment" (Auerbach 1980: 50). In subsequent studies, scholars have continued to explore the ways the fallen woman trope illuminates identity, class, and gender in the Victorian era. However, apart from Auerbach's text, few critical articles pay attention to the visual aspects of fallenness, or how characters reflect or challenge their identities as fallen women through their sartorial choices.

In this article, I investigate the visual rhetoric of costume and appearance as evidenced by fallen women in three novels: Ruth in Elizabeth Gaskell's Ruth (1853), Lady Isabel in Ellen Wood's East Lynne (1861), and Lady Audley in Mary Elizabeth Braddon's Lady Audley's Secret (1862). For purposes of my analysis, costume and appearance include both dress and jewelry - and as we shall see, jewelry plays a large role in shaping the styles of Lady Isabel and Lady Audley. Alongside rhetorical scholar

\footnotetext{
*English Department, North Dakota State University, 318 Minard Hall, Fargo, North Dakota 58108, United States; e-mail: ashleigh.petts@ndsu.edu
} 
Carol Mattingly, I argue that each character's appearance is a kind of visual rhetoric in the novels, clothing and jewelry are used to make an argument, and costumes and physical appearance are imbued with meaning. The fallen women at the heart of Ruth, East Lynne, and Lady Audley's Secret use costumes and alter their physical appearance to perform different identities. Notably, Ruth, Lady Isabel, and Lady Audley hide their fallenness through dress; and although none is ultimately successful at disguising herself, each character's attempt to use costuming to her advantage highlights the importance of sartorial/rhetorical style and performance in Victorian fiction.

\section{Genre and the concept of fallenness}

Gaskell's Ruth, Wood's East Lynne, and Braddon's Lady Audley's Secret fall at the juncture of several genres. Ruth is a social problem novel, while East Lynne and Lady Audley's Secret are two of the novels that helped establish the genre of sensation fiction (Loesberg 1986: 115). As Dolin explains, Ruth deals broadly with “... what the Victorians themselves called the 'great social evil': 'prostitution' - not, as we understand it, the sex industry, but all forms of what the Victorians classed as female social-sexual transgression" (Dolin 2011: ix). In addition, as Hatano notes, "The social message of Ruth is a call for sympathy towards women who have fallen as a result of being seduced" (Hatano 2000: 635). One of the main purposes of Ruth, then, is to illuminate the social and economic conditions of unwed mothers.

East Lynne and Lady Audley's Secret, meanwhile, are exemplary of sensation fiction, a genre popular in the 1860s. As Palmer notes, "Sensation aimed to stimulate readers' nerves, not their moral faculties" (Palmer 2009: 87). The new genre benefited greatly from advances in print technology, which allowed print materials to be mass produced quickly and cheaply. Sensation novels proved controversial both for their content and because of critics' worries over the effects of their widespread readership (Palmer 2009: 87-88). However, as Loesberg argues, sensation fiction arose from the political context of discussions about parliamentary reform (Loesberg 1986: 116). In both East Lynne and Lady Audley's Secret, sensation results from the loss of class identity (Loesberg 1986: 117). Despite their apparent lack of moral content, then, sensation novels reflected very real anxieties about rapid changes in technology and the breakdown of the class system in 1860s Britain.

While there are rather large distinctions between the social problem and sensation fiction genres, Ruth, East Lynne, and Lady Audley's Secret center themselves on a common trope in Victorian fiction: the fallen woman. The image of the fallen woman was part of a "shared cultural mythology" in the literature and visuals of the Victorian era (Auerbach 1980: 29). Women "fell" because of sexual transgressions, and the female protagonists of Ruth, East Lynne, and Lady Audley's Secret are no 
exception. Indeed, the plots of all three novels center on the consequences of Ruth's, Lady Isabel's, and Lady Audley's transgressive (and sometimes criminal) actions; in the case of Lady Audley's Secret, these actions are slowly uncovered through plot development similar to that of a detective novel. And while the phenomenon of the fallen woman existed outside of art and literature, there are stark differences between the fictional Ruth, Lady Isabel, Lady Audley, and their real-life Victorian counterparts. As Auerbach notes:

Though in life the division between fallen and respectable woman might have been reasonably fluid, art allows no return to the old familial boundaries of identity. Conventionally, the fallen woman must die at the end of her story, perhaps because death rather than marriage is the one implacable human change, the only honorable symbol of her fall's transforming power. Death does not simply punish or obliterate the fallen woman: its ritual appearance alone does her justice. (Auerbach 1980:35)

The two defining characteristics of fallen woman fiction, sexual transgression and death, are the impetus and result of the fallen woman's transformation. As we shall see, this transformation is especially visible in the visual rhetoric of the protagonists. As Ruth, Lady Isabel, and Lady Audley navigate new social identities, they adopt new styles of dress. For Ruth and Lady Isabel, especially, the best way to shed the sins of the past is to transform them through costume.

\section{Women's dress as visual rhetoric}

Scholars of design Eicher and Roach-Higgins conceptualize "dress" as "a comprehensive term to identify direct body changes and items added to the body" (Eicher and Roach-Higgins 1992: 15). For purposes of this article, dress encompasses clothing, jewelry, and other ornaments worn by characters. Dress serves much more than a material function, however; as Eicher and Roach-Higgins demonstrate, dress "precede[s] verbal communication in establishing an individual's gendered identity as well as expectations for other types of behavior (social roles) based on this identity" (Eicher and Roach-Higgins 1992: 17). Dress, then, is essential in constructing and challenging gender and other social roles.

Despite its primacy in shaping identity, dress has been neglected in studies of visual rhetoric. This neglect is particularly problematic in assessing women's rhetorical contributions. In her study of rhetorical style in nineteenth-century America, Carol Mattingly notes that for nineteenth-century women, "Gender, inscribed on and around women's bodies, was constructed largely in the visual impact created by their clothing 
and appearance... gender aligned with location, a specifically assigned 'sphere"" (Mattingly 2002: 1). Middle-class women of the Victorian era on both sides of the Atlantic were essentially defined by their clothing; gender and class identities were read through appearance. What's more, the Victorian ideology of separate spheres for women and men meant that women were identified with and assigned to the domestic sphere, responsible for taking care of the home and children. Outside of the home, women dressed themselves according to the temporal/social situation in which they found themselves. As Mattingly explains:

Woman's gendered appearance, inscribed by an elaborately ornamented and detailed wardrobe, not only defined her femininity but also systematically and simultaneously distinguished her place. That is, the cut and detail of her dress, often accompanied by the specific style of her hair, signified her proper temporal location - the ballroom gown, lawn party dress, riding habit, walking dress, or morning wrapper - as well as social or class position. (Mattingly 2002: 7)

Dress, then, encompassed a number of communicative and ideological functions for women in the Victorian era.

As Mattingly demonstrates, dress had an "established and well-defined rhetoric" (Mattingly 2002: 6), one which women could use to project an image and define how they wanted to be seen (Mattingly 2002: 8). This visual rhetoric of dress, which I call sartorial/rhetorical style, is also evident in Victorian fiction. Although fiction is not always a mirror image of society, the social problem and sensation novels of the midVictorian era reflect social preoccupations, and the authors of Ruth, East Lynne, and Lady Audley's Secret aimed for realism in their novels' settings and in details about the daily lives of their characters. In addition, each of the novels pays particular attention to the protagonists' dress, and I argue that this focus on dress is an important narrative device through which questions of personal, gender, and socioeconomic identities of fallen women (and by extension, women in general) are interrogated.

In the following sections, I present evidence of the importance of dress and appearance in Ruth, East Lynne, and Lady Audley's Secret through the characters of Ruth, Lady Isabel, and Lady Audley, respectively. While contemporary readers may gloss over descriptions of characters' dress, my reading of dress and appearance in the novels aims to demonstrate the centrality of sartorial/rhetorical style to the fallen woman genre. Several similarities among Ruth, Lady Isabel, and Lady Isabel stand out: all are described as innocent or childish (that is, all have characteristics of the Victorian feminine ideal); all take new names to conceal their true identities; and all make use of costume or disguise to construct new identities. 


\section{Ruth: disguising shame}

In Ruth, the eponymous character's life is marked by the sartorial. Indeed, we can trace the transformations in Ruth's life through her clothing. At the beginning of the novel, Ruth works in Mrs. Mason's dress shop. Ruth is an orphan, and she works for meager wages to support herself. Despite her hardship, Ruth is in possession of a great beauty, and Mrs. Mason insists that she represent the dress shop by attending the town's annual hunt-ball, mending dresses as necessary. Ruth's best frock, a Sunday black silk described as "somewhat worn and shabby" (Gaskell 2011: 11), is inappropriate for the ball, but it will have to do.

Indeed, Ruth's unhappy station in life is reflected in both her lifestyle and her material goods. Ruth is miserable working for Mrs. Mason, and her misery is particularly acute on Sundays:

What became of such as Ruth, who had no home and no friends in that large populate desolate town? She had hitherto commissioned the servant, who sent to market on Saturdays for the family, to buy her a bun or biscuit, whereon she made her fasting dinner in the deserted workroom, sitting in her walking-dress to keep off the cold, which clung to her in spite of shawl and bonnet. (Gaskell 2011: 29)

The image that Ruth projects, cold and alone in a workroom with a walkingdress, shawl, and bonnet, is a desperate one. It contrasts markedly with the one she projects after she meets Mr. Bellingham, and in particular during her time with him in Wales. Mr. Bellingham convinces Ruth to leave with him after Mrs. Mason is scandalized finding the two of them in a public house late on a Sunday evening. Ruth and Mr. Bellingham leave by carriage and eventually travel to an inn in Wales. Ruth finds herself alternately joyful in her love and desire to please Mr. Bellingham and full of shame when townspeople comment on the impropriety of her situation.

The narrative never describes the exact moment of Ruth's fall. However, we can find clues in the description of her appearance, as Ruth and Mr. Bellingham spend time alone together in the Wales countryside:

Down in that green hollow they were quite in harmony. Her beauty was all that Mr. Bellingham cared for, and it was supreme. It was all he recognised of her, and he was proud of it. She stood in her white dress against the trees which grew around; her face was flushed into a brilliancy of colour which resembled that of a rose in June; the great heavy white flowers dropped on either side of her beautiful head, and if her brown hair was a little disordered, the very disorder only seemed to add a grace. (Gaskell 2011: 61-62) 
Here, Ruth's white dress and the white flowers that surround her head suggest innocence, purity, and virginity. Ruth's graceful beauty complements her angelic clothing and natural ornaments.

Ruth's innocence (and her innocent white clothing) is short-lived; she has a sexual relationship with Mr. Bellingham, and he abandons her. Thurston Benson, a Dissenter preacher residing in Eccleston, offers to take her in. The period after her fall marks the beginning of her physical and social transformation. Benson and his sister Faith (most often referred to in the novel as Miss Benson) decide to protect Ruth, who is also pregnant, by lying to the public; Ruth will no longer be Ruth, but Mrs. Denbigh, a widow.

The primary means by which Ruth expresses her new identity is clothing. As a widow, Ruth must now wear a black gown. Fittingly, Ruth stitches it herself, and she finds herself restless and troubled when she completes it (Gaskell 2011: 107). The gown is symbolic of her new situation in life and the trouble she finds herself in.

The next item Ruth must wear to perform her new identity is a wedding ring. Again, this item of dress makes her uncomfortable. When Faith realizes that Ruth is missing a ring, she quickly works to remedy the situation before Mrs. Bradshaw comes to call on them: "She pulled out an old wedding-ring, and hurried it on Ruth's finger. Ruth hung down her head, and reddened deep with shame; her eyes smarted with the hot tears that filled them" (Gaskell 2011: 116-117). For Ruth, the wedding ring is yet another reminder of the social shame surrounding her fallenness.

The final alterations to Ruth's appearance involve her hair. When Sally, the Bensons' servant, notices Ruth in a "long, soft, white dressing-gown, with her luxuriant brown hair" (Gaskell 2011: 117), she becomes suspicious of Ruth and offers to cut her hair and give her a widow's cap to protect the Benson family from shame. Ruth's appearance belies her true identity, and Sally insists that Ruth further alter her appearance, telling her, "'Widows wear these sort o' caps, and has their hair cut off; and whether widows wears wedding-rings or not, they shall have their hair cut off - they shall. I'll have no half work in this house"' (Gaskell 2011: 117-118). Sally takes it upon herself to remedy the "half work" of Ruth's disguise.

The hair-cutting scene that follows is crucial to Ruth's transformation. More so than a black gown, wedding-ring, and widow's cap, having her hair cut short is the most radical way Ruth alters her physical appearance. It is also the most psychologically painful. It is important to note that Ruth does not cut her hair herself, but rather submits without protest to Sally's demand. In the pivotal scene, we read:

Sally produced the formidable pair of scissors that always hung at her side, and began to cut in a merciless manner. She expected some remonstrance 
or some opposition, and had a torrent of words ready to flow forth at the least sign of rebellion; but Ruth was still and silent, with meekly-bowed head, under the strange hands that were shearing her beautiful hair into the clipped shortness of a boy's. (Gaskell 2011: 118)

Ruth's physical transformation into a widow coincides with the beginning of her repentance, and she accepts the pain and shame of short hair as part of the process. The next day, she comes down to breakfast in her widow's cap, and we read that "her smooth, pale face, with its oval untouched by time, looked more young and child-like than ever, when contrasted with the head-gear usually associated with ideas of age" (Gaskell 2011: 121). Ruth, a young woman who is practically a child, must forever perform the role of widow.

Although Ruth feels shame internally, the primary purpose of her sartorial/ rhetorical style is to disguise herself to prevent public shame. For quite a long time, her Mrs. Denbigh disguise is successful. Ruth earns the trust and admiration of the Bradshaw family, and she eventually works as governess to the Bradshaws' two small children. After her first Sunday appearance at church, Mr. Bradshaw sends Ruth "muslin in aid of any preparations Mrs. Denbigh might have to make" (Gaskell 2011: 128). The gift of muslin is telling; Mr. Bradshaw wishes to aid Ruth in clothing her future child.

For her part, Ruth chooses to clothe herself in a style that mirrors her internal state. After receiving the muslin from Mr. Bradshaw, she is inspired to work on her own clothing:

She asked Sally to buy her (with the money produced by the sale of a ring or two) the coarsest linen, the homeliest dark blue print, and similar materials; on which she set busily to work to make clothes for herself; and as they were made, she put them on; and as she put them on, she gave a grace to each, which such homely material and simple shaping had never had before. Then the fine linen and delicate soft white muslin, which she had chosen in preference to more expensive articles of dress when Mr. Bellingham had given her carte blanche in London, were cut into small garments, most daintily stitched and made ready for the little creature. (Gaskell 2011: 131)

Ruth dresses herself plainly and with rougher materials so that her child may have better clothing. Her sartorial/rhetorical style promotes simplicity and humility, and it reflects Ruth's desire to repent for her sexual sin. 
Ruth exhibits a similar sartorial/rhetorical style for much of the remainder of the novel. When Jemima Bradshaw visits Ruth for tea and to discuss her child's christening, Ruth is described as being "very beautiful in her quiet mournfulness; her mean and homely dress left herself only the more open to admiration, for she gave it a charm by her unconscious wearing of it that made it seem like the drapery of an old Greek statue - subordinate to the figure it covered, yet imbued by it with an unspeakable grace" (Gaskell 2011: 150). While Jemima and the other members of the Bradshaw family interpret Ruth's mourning as appropriate for the death of her husband, it is, of course, a reflection of how Ruth sees the state of her soul. Ruth's "mean and homely dress" is yet another way she performs widowhood.

Ruth does, however, dress up when the situation calls for it. For an evening dinner at the Bradshaw home, she wears her finest gown of dark grey, and Miss Benson quills a ruff for her. Along with her bonnet and shawl, Ruth's appearance earns the admiration of her son Leonard and Miss Benson. Ruth, too, is pleased: "II think my ruff looks so nice,' said Ruth, with gentle pleasure. And indeed it did look nice, and set off the pretty round throat most becomingly. Her hair, now grown long and thick, was smoothed as close to her head as its waving nature would allow, and plaited up in a great rich knot low down behind. The grey gown was as plain as plain could be" (Gaskell 2011: 187).

As time passes, Ruth is able to alter her sartorial/rhetorical style to suit the temporal social situations she finds herself in. Although she still wears plain clothing, she allows her hair to regrow. Her widow's disguise has been successful, and Ruth can perform her adopted identity in less rigid ways.

Eventually, of course, Ruth's true identity as a fallen woman is uncovered. Fittingly, it is Mrs. Pearson, the dressmaker, who alerts Jemima Bradshaw to the truth of Ruth's past, and while Jemima keeps this information to herself, Mrs. Pearson eventually spreads rumors of Ruth's situation throughout town. Ruth is denounced by Mr. Bradshaw and publicly shamed. She is eventually redeemed, however, through her service as a nurse; her repentance cannot be completed in the home. As Hatano argues, Ruth's redemption through service outside of the home is related to the ideology of the spheres:

The domestic ideology prevalent among the middle classes does not allow a fallen woman to be redeemed in the private sphere where the Victorian ideal of virtuous womanhood is enshrined. According to this belief, home is the place where men, pampered with the self-sacrificial care of "the angel in the house," recover the morality and humanity that have been damaged in the harsh commercial world. This place must not 
be contaminated by the presence of a fallen woman. Thus, Ruth must eventually redeem her sin outside the sacred home. (Hatano 2000: 637638)

Furthermore, this redemption is dependent on the blessings of the patriarchal system. Not only did Ruth have to perform the role of widow through gendered clothing, she also must perform redemption in a way that satisfies the (male) public. As Milota points out:

It is the male medical practitioners and townsmen who proclaim her talent as a healer during the typhus outbreak and thereafter dismiss her previous moral transgressions. Whether Gaskell did it consciously or not, Ruth ultimately confirms the power of the male voice in determining the status and acceptance of women. In this sense, the most persistent underlying point of Ruth is that if men contributed to Ruth's "fall" in society, it must also be men who redeem her. (Milota 2013: 487)

Despite Ruth's successful sartorial/rhetorical style and performance as a widow, she is ultimately judged pure by adopting another identity altogether, that of the "angelic nurse" (Hatano 2000: 639).

Ruth dies at the end of the novel, fulfilling the inevitable narrative conclusion of the fallen woman. Hatano argues that Ruth must also die to "conform to the domestic ideal of femininity associated with delicate fragility" (Hatano 2000: 639). Ultimately, Ruth sacrifices herself by caring for her former lover; she contracts typhus fever and quickly passes away. And although the novel does not describe Ruth's deathbed attire, we can imagine her wearing a white gown that reflects her final, redeemed identity of an angelic, pure woman.

\section{Lady Isabel: deceiving the household in service of motherhood}

Ruth and Lady Isabel, the protagonist of Wood's East Lynne, come from different social classes but share a few defining characteristics: both are exceedingly beautiful, and both have difficulties with money as single women. In contrast to Ruth, however, Lady Isabel dresses herself in finery. In the novel's earliest description of Lady Isabel's dress, we see her in a fashionable tippet and gloves (Wood: 2008: 14). In the same scene, her relative Mrs. Vane shames her for only wearing a "cross and some rubbishing pearl bracelets" instead of diamonds (Wood 2008: 15). Lady Isabel replies that she wears the cross and bracelet because her mother, who had passed away long 
ago, gave them to her; besides, Lady Isabel insists that she "[does] not like to be too fine" (Wood 2008: 16).

Lady Isabel's sense that she does not want to appear "too fine" is telling. Although she is an upper-class woman, she lacks basic knowledge about fashion (along with other womanly duties, such as how to run a household). She calls a dress a "frock" (Wood 2008: 18), and Mrs. Vane teases her about it. When Captain Levinson breaks the chain and cross given to her by her mother (a clear foreshadowing of the destruction he will bring to her life), Lady Isabel is distraught. Although the cross is not fashionable, it is meaningful. Lady Isabel's initial sartorial/rhetorical style, then, is characterized by fine clothing appropriate to her social class, but also ornamentation that expresses her values.

Similar to Ruth, Lady Isabel, too, projects a different image according to the temporal situation. For her first appearance in the church at East Lynne, her dress is characterized as "too plain", consisting of "a clear muslin dress with small lilac springs upon it, and a straw bonnet" (Wood 2008: 65). Later, during the concert that takes place on the night of her father's death, we read:

A shining vision was standing before him [Lord Mount Severn, Lady Isabel's father], a beauteous queen, a gleaming fairy; he hardly knew what she looked like. She had put on a white lace dress and her diamonds; the dress was rich, and the jewels gleamed from her hair, from her pretty neck, from her delicate arms; and her cheeks were flushed and her curls were flowing. (Wood 2008: 76).

Lady Isabel continues to wear her fine clothing throughout the night, as she refuses to take the time to change in case she misses word about her father's illness.

The day after Lord Mount Severn's death, Lady Isabel does change her clothes; she wears a "pretty morning dress of peach-coloured muslin", and the men who had invaded the estate of East Lynne to collect the late Lord's debts are marveled by her youth, innocence, and childlike appearance (Wood 2008: 91). Her financial situation is so precarious, and Lady Isabel herself so unaware of how debts are repaid, that she is unsure if her clothes are her own (Wood 2008: 98). Similar to Ruth, then, Lady Isabel exhibits characteristics of the ideal, virtuous Victorian woman.

After her father's death, Lady Isabel marries Mr. Carlyle and moves in with him at East Lynne. During her marriage, Lady Isabel's sartorial/rhetorical style continues to be appropriate to her social class. Lady Isabel projects an image of happiness and harmony in her mixed upper-class/middle-class home. She is, at first, totally devoted to her husband, even falling asleep as she awaits his arrival from work. We read that 
"her bonnet and parasol lay at her feet, her scarf had dropped, and she looked like a lovely child" (Wood 2008: 150). Later, at a dinner with Barbara Hare, the woman she believes to be her rival for Carlyle's affections, Lady Isabel dresses to assert her social power over Barbara: "She wore a costly black lace dress, its low body and sleeves trimmed with white lace as costly: and ornaments of jet. She looked inexpressibly beautiful" (Wood 2008: 158). For the most part, Lady Isabel's sartorial/rhetorical style reflects the comfort of her position.

Eventually, however, the image of a happiness and harmony is shattered, as Lady Isabel becomes increasingly convinced that her husband is having an affair with Barbara. As Hansson and Norberg note, Lady Isabel is a "passive victim of her emotions" (Wood 2008: 156). Her inability to express her jealousy and her anger towards her husband leads to her downfall (Hansson and Norberg 2012: 165). Overcome with jealousy and certain that her husband loves Barbara, she leaves East Lynne with Captain Levinson and elopes with him in Europe. Lady Isabel is transformed from a respectable wife to a fallen woman.

Similar to the consequences of Ruth's fall from grace, Lady Isabel must alter her style to reflect her new position in life. After Captain Levinson fathers a child with her but refuses to marry her, Lady Isabel dresses as if she has been struck ill; we read that "she wore an invalid cap, and a think woolen invalid shawl, and she shook and shivered perpetually; though she had drawn so close to the wood fire that there was a danger of her petticoats igniting" (Wood 2008: 289). Lady Isabel's psychological illness - her shame and despair at leaving her husband and children and her subsequent betrayal by Levinson - is evident in her attire.

Lady Isabel's most lasting transformation occurs after a train wreck. After the accident, which resulted in the death of her child by Levinson, Lady Isabel sends a note informing the new Lord Mount Severn of the tragedy. Eventually, she is believed to be dead, which allows her to adopt a new identity, that of Madame Vine, French governess.

Lady Isabel's physical transformation is astounding. The first full description of it is worth quoting at length:

She limps slightly as she walks, and stoops, which takes from her former height. A scar extends from her chin above her mouth, completely changing the character of the lower part of her face, some of her teeth are missing, so that she speaks with a lisp, and the sober bands of her grey hair - it is nearly silver - are confined under a large close cap. She herself tries to make the change greater, that the chance of being recognised may be at an end, for which reason she wears 
distinguishing green spectacles, or, as they are called, preservers, going round the eyes, and a broad band of grey velvet coming down low upon her forehead. (Wood 2008: 388-389)

Lady Isabel's shocking physical transformation is the result of her accident, her emotional state, and her efforts to disguise herself. To further disguise herself, we read that she wears "frightful 'loose jackets"" which do not fit her well, a bonnet which covers her face, and a thick veil (Wood 2008: 389). Lady Isabel completely adopts the new identity of Madame Vine, and the primary way she expresses that identity is through her clothing and appearance. Similar to Ruth, Lady Isabel disguises herself to live and earn money without being subjected to intense social shame. Unlike Ruth, Lady Isabel takes her disguise a step further.

After her fall, Lady Isabel longs to be reunited with her children. Her desire to be a mother to them is so strong, she accepts a position as governess at East Lynne, risking detection by Carlyle, his new wife, Barbara, and the children. However, her sartorial/rhetorical style provides some protection; Madame Vine's introductory letter describes her as "the oddest-looking person: wears caps, enormous bonnets, and has a great scar on her mouth and chin; and though she can't be more than thirty, her hair is grey: she is also slightly lame" (Wood 2008: 398). Lady Isabel/Madame Vine has completely overhauled her wardrobe; in the process, she overhauls her life.

Once she arrives at East Lynne, Lady Isabel has little fear of being detected ("so effectually was she disguised, by nature's altering hand, or by art's" (Wood 2008: 402)). Justice Hare, Barbara Hare's father, tells Lady Isabel that she looks French, focusing on her glasses and the dress that hides her figure (Wood 2008: 422). Even after she breaks her glasses, no one recognizes her - although Miss Corny, Carlyle's sister, sees a resemblance (Wood 2008: 470). Lady Isabel is quick to replace her glasses, too, and she remains undetected until her servant Joyce sees her outside in the middle of the night. Still, Joyce tells no one of her discovery, fearing she had seen a ghost. Lady Isabel deceives an entire household so that she can be around her children. Her false Madame Vine/governess identity allows her to perform her true role as mother, and that identity is impossible without Lady Isabel's sartorial/rhetorical style.

Lady Isabel's disguise and sartorial/rhetorical style support her new identity until the very end. Similar to Ruth, Lady Isabel is redeemed through nursing - except that this time, she nurses her own child, William, as he passes away. Lady Isabel fades quickly after the death of her child. On her deathbed, Miss Corny and her husband both recognize her, and Lady Isabel asks for forgiveness. Again, the novel does not give us a description of her attire as she passes; however, we can imagine her dressed as the noble Lady Isabel before her fall, reclaiming her true identity upon her death. 


\section{Lady Audley: performing nobility for social mobility}

Unlike Ruth and Lady Isabel, Lady Audley's fall in Lady Audley's Secret is not the result of seduction but rather her ambition and desire to make a better life for herself. Readers' knowledge of Lady Audley's transgressions unfolds slowly, as Robert Audley, a lawyer who investigates his friend George Talboys' disappearance, unravels the elaborate disguise Lady Audley has constructed for herself. Similar to Ruth and Lady Isabel, Lady Audley adopts a new name and identity, as she begins life as Helen Maldon. After George Talboys marries her and then abandons her to work in Australia, Helen fakes her own death, gives up her child, and works as a governess, assuming the name Lucy Graham. She marries Sir Michael Audley, becoming Lady Audley. Along the way, she attempts to murder her first husband, George, and sets fire to the public house Robert Audley is staying in. Lady Audley's sexual transgression is bigamy, but her sensational criminal acts add to her deviance.

When we first meet the future Lady Audley, she is described as beautiful and charming, a woman "blessed with that magic power of fascination by which a woman can charm with a word or intoxicate with a smile" (Braddon 2012: 11). As Sir Michael proposes to her, her reaction unsettles him; what's more, this same scene is our first introduction to her sartorial/rhetorical style, as we read that "she was still on the ground at his feet, crouching rather than kneeling, her thin white dress clinging about her, her pale hair streaming over her shoulders, her great blue eyes glittering in the dusk, and her hands clutching at the black ribbon about her throat, as if it is strangling her" (Braddon 2012: 16). Later, we read that the black ribbon has a trinket attached to it, a ring wrapped in paper (Braddon 2012: 17). Similar to Lady Isabel, Lucy Graham/Lady Audley wears a seemingly sentimental item as a piece of jewelry.

It is jewelry, too, that sparks the undoing of Lady Audley. The night before he realizes George Talboys is missing, Robert Audley spends time at Audley Court with Sir Michael and Lady Audley. Lady Audley entertains her husband and guest with music; however, Robert eventually notices something is amiss:

He amused himself by watching her jeweled white hands gliding softly over the keys, with the lace sleeves dropping away from her graceful arched wrists. He looked at her pretty fingers one by one; this one glittering with a ruby heart; that encoiled by an emerald serpent; and about them all a starry glitter of diamonds. From the fingers his eyes wandered to the rounded wrists: the broad, flat, gold bracelet upon her right wrist dropped over her hand, as she executed a rapid passage. She stopped abruptly to re-arrange it; but before she could do so, Robert Audley noticed a bruise upon her delicate skin. (Braddon 2012: 79-80) 
Lady Audley blames the bruise on her tying a piece of ribbon around her skin; Robert is skeptical of her explanation after he notices that the bruise looks like it came from someone's hand, complete with the mark of a ring. He concludes that Lady Audley is lying, and this first conclusion leads him on a long journey to unearth her true identity: that of Helen Talboys, a woman who comes from poverty and abandons her child to position herself for a better life. Lady Audley's disguise is that of an upper-class woman, and she uses her sartorial/rhetorical style to perform nobility. More so than Lady Isabel in East Lynne, Lady Audley dresses in expensive, fashionable clothing. She wears long furs on a trip to London (Braddon 2012: 127), and she wears such stylish items as a pale pink muslin morning dress to breakfast (Braddon 2012: 70).

Indeed, Lady Audley's noble disguise and her outward trappings of femininity are so effective, she fools almost all the men and women she comes into contact with (Klein 2008: 165). In one scene, as she is tending to her ill husband, she is described as saintly: "Lucy Audley, with her disordered hair in a pale haze of yellow gold about her thoughtful face, the flowing lines of her soft muslin dress-gown falling in straight folds to her feet, and clasped at the waist by a narrow circlet of agate links, might have served as a model for a mediaeval saint" (Braddon 2012: 184)

Here, Lady Audley performs the feminine ideal. As part of her disguise, the feminine ideal helps her appeal to kind of moral and social superiority (Matus 1993: 334), further cementing her assumed identity.

Eventually, Lady Audley's elaborate scheme begins to fall apart. She maintains her sartorial/rhetorical style until the very end, however. Before her confession, contemplating how to outsmart Robert Audley, she projects the perfect image of Victorian womanhood:

My lady's easel stood near the window, bearing witness to my lady's artistic talent, in the shape of a water-coloured sketch of the Court and gardens. My lady's fairy-like embroideries of lace and muslin, rainbowhued silks, and delicate tinted wools littered the luxurious apartment; while the looking-glasses, cunningly placed at angle and opposite corners by an artistic upholsterer, multiplied my lady's image, and in that image reflected the most beautiful object in the enchanted chamber. (Braddon 2012: 250)

Even after she sets fire to the public house and waits for news of what she expects will be Robert's demise, Lady Audley uses "her beauty as a weapon" and dresses herself in silk and cashmere (Braddon 2012: 287). Lady Audley is always "on", always performing the part of the rich, upper-class lady. 
Indeed, it is Lady Audley's ambition to a higher class that represents her largest transgression. As Matus argues, "What primarily seems to be the matter with Lady Audley is that she threatens to violate class boundaries and exclusions, and to get away with appropriating social power beyond her entitlement" (Matus 1993: 335). What's more, Lady Audley uses deception to further her position in life. As Klein notes, "Lady Audley gives Sir Michael the illusion that she conforms to the Victorian ideal of womanhood and that he can play the ideal Victorian male, but in reality she violates gender, social and moral boundaries" (Klein 2008: 170-171). Although Lady Audley appeals to a hereditary female madness to explain her actions, Dr. Mosgrave, a physician brought in by Robert to examine her, declares Lady Audley not mad but dangerous (Braddon 2012: 323).

Lady Audley is sent away to a maison de santé to protect the honor of Sir Michael and avoid scandal for the family. As she leaves Audley Court, she wraps herself in furs, and we read that "her mercenary soul hankered greedily after the costly and beautiful things of which she had been mistress. She had hidden away fragile tea cups and covered vases of Sèvres and Dresden among the folds of her silken dinner dresses. She had secreted jewelled and golden drinking cups amongst her delicate linen" (Braddon 2012: 326). Until the very end, she clings to her uppermiddle class identity and style. Once she arrives at the maison de santé, however, her disguise is no longer convincing:

Amid all the faded splendour of shabby velvet, and tarnished gilding, and polished wood, the woman dropped into an arm-chair, and covered her face with her hands. The whiteness of them, and the starry light of diamonds, trembling about them, glittered in the dimly-lighted chamber... She points to the door with a sharp imperious gesture; so rapid that the silken drapery about her arm makes a swooping sound as she lifts her hand. (Braddon 2012: 331-332)

Lady Audley dies a few years later from maladie de langueur. Unlike Ruth and Lady Isabel, she is not redeemed, and rather than joyfully reclaiming her true identity after years of suffering, her old identity is forced upon her as she is exiled in shame.

\section{Conclusion: negotiating social roles through sartorial/rhetorical style}

In the Victorian era, a woman's dress helped to construct her identity. Ruth in Ruth, Lady Isabel in East Lynne, and Lady Audley in Lady Audley's Secret use sartorial/rhetorical style to help them negotiate personal, gender, and socioeconomic identities. All three characters adopt new personal identities, and while they are all 
gendered female, their sartorial/rhetorical style reinforces their femininity - especially when that femininity is called into question through their fallen state. Finally, both Lady Isabel and Lady Audley use their sartorial/rhetorical style to help them navigate new socioeconomic roles, as class divisions in both novels are blurred when Lady Isabel becomes the governess Madame Vine and Helen Talboys reinvents herself as Lucy Graham and eventually Lady Audley.

Sartorial/rhetorical style, as we have seen, is central to the development of the fallen woman trope in Ruth, East Lynne, and Lady Audley's Secret. One of the primary means by which each woman expresses her fallenness is through dress, and as each woman goes through a series of transformations, dress and identity are inextricably intertwined. As Mattingly reminds us, for nineteenth-century women, "Dress clearly repeated definitions of race, class, gender, and morality, all closely associated with character" (Mattingly 2002: 12). For nineteenth century fallen women in fiction, dress represents the power to change, to take control of their lives - even if only for a little while.

\section{References}

Auerbach, N. (1980). The Rise of the Fallen Woman. Nineteenth-Century Fiction, 35(1), 29-52. JSTOR. (5 November 2018) <https://www.jstor.org>.

Braddon, M. E. (2012). Lady Audley's Secret. Oxford: Oxford University Press.

Dolin, T. (2011). Introduction. In: E. Gaskell, Ruth, Oxford: Oxford University Press, vii-xxviii.

Eicher, J. B. and M. E. Roach-Higgins (1992). Definition and Classification of Dress: Implications for Analysis of Gender Roles. In: R. Barnes and J. B. Eicher (eds.), Dress and Gender: Making and Meaning, 8-28. New York, NY: Berg Publishers. University of Minnesota Libraries Digital Conservancy. (4 December 2018) $<$ https://conservancy.umn.edu/>.

Gaskell, E. (2011). Ruth. Oxford: Oxford University Press.

Hansson, H. and C. Norberg (2012). Storm of Tears: Emotion Metaphors and the Construction of Gender in East Lynne. Orbis Litterarum, 67(2), 154-170.

Hatano, Y. (2000). Evangelicalism in Ruth. The Modern Language Review, 95(3), 634-641. JSTOR. (8 November 2018) <https://www.jstor.org>.

Klein, H. (2008) Strong Women and Feeble Men: Upsetting Gender Stereotypes in Mary Elizabeth Braddon's Lady Audley's Secret. Atenea, 28(1), 161-174.

Loesberg, J. (1986). The Ideology of Narrative Form in Sensation Fiction. Representations, 13, 115-138. JSTOR. (6 November 2018) <https://www.jstor.org>. 
Mattingly, C. (2002). Appropriate[ing] Dress: Women's Rhetorical Style in NineteenthCentury America. Carbondale, IL: Southern Illinois University Press.

Matus, J. (1993). Disclosure as 'Cover-up:' The Disclosure of Madness in Lady Audley's Secret. University of Toronto Quarterly, 62(3), 334-355.

Milota, M. (2013). But Every Man Cannot Be a Surgeon: Elizabeth Gaskell's ManySided Medical Practitioners. Orbis Litterarum, 68(6), 463-505. Wiley Online Library. (7 November 2018) <https://www.onlinelibrary.wiley.com/>.

Palmer, B. (2009). Are the Victorians Still with Us? Victorian Sensation Fiction and Its Legacies in the Twenty-First Century. Victorian Studies, 52(1), 86-94.

Wood, E. (2008). East Lynne. Oxford: Oxford University Press. 